\title{
Metal Organizations Adaptation Strategy in Managing Mangrove Area in Farmers' Work Culture in Tawang Mas, Semarang
}

\author{
Zilda Nur Aulia, Af'idatul Lathifah, and Siti Maziyah * \\ Department of Anthropology, Faculty of Humanities, University of Diponegoro, Semarang - 50275, \\ Central Java, Indonesia \\ *Department of history, Faculty of Humanities, University of Diponegoro, Semarang - 50275, Central \\ Java, Indonesia
}

\begin{abstract}
This research is seen as a strategy for structuring the terrestrial and marine environment as well as examining organizational responses in maintaining the existence of mangroves. Qualitative methods are used in conjunction with the Chair of the Organization. Mekar Tani Lindung (METAL) is a group of farmers and fishermen to tackle sea water abrasion by planting mangrove trees at several points. The green view of the sea breeze is a combination used to form MMEP (Edu Maroon Mangrove Park) tours. However, the existence of a tourist point at the end of the Ahmad Yani Airport runway is the main reason for the closure of permanent tourist access. METAL with the basis of mangrove development as a concern for the environment and improving the mangrove economy in a sustainable manner.
\end{abstract}

\section{INTRODUCTION}

Mangrove trees with the durability of holding water from sea abrasion make trees, water and cool wind one way to relieve fatigue from the hustle and bustle of urban life. Mangrove ecosystems have ecological benefits, such as providing nutrients, laying eggs and foraging for aquatic biota, preventing intrusion, abrasion, and blocking waves and strong winds. The garden is a building structure that includes the three potential conditioning. Parks are also always developed and become an icon of an area; besides that, they can add to the existing tourism system in Semarang. The establishment of MMEP (Maroon Mangrove Edu Park), a nature-based tourist spot and maintains and preserves natural ecosystems, also improves the socio-economic system of local community groups. The collaboration between these two social groups has made it an organization called METAL (Mekar Tani Lindung).

The formation of 2 social groups whose members are mutually bound by a sense of kinship. Make work as one of the increasingly attached collaborations. Men or farmers, fishers, and farmers involved in this tourism, women's groups also take part in it. This MMEP is purely formed and managed by residents, thereby making regional benefits and relations between residents into a close brotherhood unit.

The distance of the tourist boundary adjacent to the landing and take-off of Ahmad Yani airport makes this tour questionable for the safety of tourists and the airport policy, which states that the Maroon Mangrove Edupark Ecological tour is permanently closed. This tourist spot, which was built and managed directly by METAL, had to be closed, but it didn't stop 
there; these METAL members continued to preserve Mangroves in existing milkfish ponds and executed Mangroves by planting them in their yards or simply planting them in pots. The Mekar Tani organization maintains its organization even though the area is different.

\section{RESEARCH METHODS}

Based on this method, you can collect data based directly in the field to understand and synchronize the events that occur. The research method can also be found on Observations, Interviews, and Documentation. Observations at the research site allow the authors to see and analyze local events to adjust the circumstances and arrangements built by METAL. Interviews are important because by making informants the primary source of understanding about milkfish ponds and mangroves, this interview also invites the author to understand better the socio-cultural style of these farmers in educating milkfish and mangrove ponds.

The determination of the informants was taken with several METAL members in Tawang Mas, approximately five people, one of them directly by the Chairman of METAL, Mr Rosmadi. The research has started on February 24, 2021. In addition, there will be a snowballing selection of informants from the Tawang Mas community to determine the participation and response of local people in mangrove follow up in different areas. Participant observations and in-depth interviews by researchers by directly observing the development of Mangroves being planted in pots at one of the METAL members' houses also looking for samples from Tawang Mas residents and some Mangrove managers who are used as home production. Primary data collection by meeting face to face with several METAL members to find out the Mangrove follow-up after the closing of MMEP (Maroon Mangrove Edu Park).

\section{RESULTS AND DISCUSSION}

This MMEP is purely formed and managed by residents, thereby making regional benefits and relations between residents into a close brotherhood unit. The coastal area is a transitional area between land and marine ecosystems. Partners who work together are enough supporters and sponsors to add mangrove seedlings to be superior to Semarang tourism. This mangrove natural tourism area must be preserved and maintained its ecosystem. The organizational structure and rules used are also an attraction and reference for visitors to travel.

Mangrove ecosystem management strategies as educational ecotourism are optimizing educational programs by coordinating with school institutions to visit environmental in MMEP, Organization of a social group formed on togetherness, habits and the same goal in one thing. Organizational structure has consequences for changing behaviour and the value characteristics of the people in the organizational structure.METAL (Mekar Tani Lindung) is a group of farmers and fishermen formed with harmony between land and sea workers. METAL is a forum for the unity of social beings formed based on tourism which now must maintain the existence of Mangroves which are not only useful in the present but will also be useful in the future.

Tawang Mas is the replacement area for Tugurejo as the spread of mangrove planting, with the cessation of ecological tourism not being a matter of dismantling social groups that have been created. The head of METAL maximizes the way. Mangroves can change the perspective of coastal children who think that Mangroves are sufficient to prevent abrasion but can convince Mangroves are plants that can be utilized every part of it. As is well known, Mangroves grow well in seawater, but METAL can design the survival of Mangroves in the soil in pots but still with the strategy used. Mangroves as an adhesive for social groups must be maintained even though the place of the main founder has not been built. Three dimensions 
are needed to measure the sustainability system, namely the ecological, economic, and sociocultural dimensions [1].

Mangroves which is used as a tourist place shows the development of ways of thinking and progress managed by the community. Tourism management that is managed and formed directly by the local community shows modern thinking in it. Trees are a green ecology needed by urban residents who long for nature. Milkfish ponds are artificial ponds that arrange the soil on the edges to form a pond that is sufficient for fish cultivation. Based on the theoretical basis of Ferdinand Tonnies, who explained the existence of the term Gesellschaft related to milkfish fishers and farmers, this social group developed and formed an organization known as METAL (Mekar Tani Lindung).

A. Terry Rambo (1981:6-9), the relationship between farmers as a social system and agricultural land as an agricultural ecosystem, is mediated by energy, material and information [2]. This theory is The Human Ecology which is associated with METAL (Mekar Tani Lindung) as a social group that stands as an influential social system because of human relations with humans. Meanwhile, milkfish ponds and mangroves are places and areas for METAL to manage nature. The relationship between humans and ecological systems are interrelated and has become a unified whole and beneficial.

The environment can influence the way of thinking and patterns of human behaviour to create a new culture that is understood by the environment. British anthropologist Daryll Forde concludes in his book, Habitat, Economy and Society (1934), [3] "between the physical environment and human activity there is always a specific set of goals and values, knowledge and belief: in other words, cultural patterns". The fishing groups make the centre of their activities in the pond environment because it has ecological value so that social relationships are formed. The ecological value is taken by fish cultivation, while this Tawang Mas village woman produces mangroves.

New adaptations built into the environment need to be convinced of new territorial benchmarks. Tugurejo, which started as the development and initial form of the Mangrove, which has become its natural nature, grows at the bottom of the sea. Tawang Mas is an area similar to Tugurejo, which is close to marine life or known to coastal communities; most people have focused on milkfish ponds managed by each METAL member. The METAL chairman, with a sense of Mangrove's existence who feels that there are many benefits in managing it, and his wife, who still produces homemade snacks from Mangrove leaves and the fruit can also be exported into natural drink juices are well known to several Semarang SMEs.

METAL is engaged in ecological, social and economic development. The ecological aspect maintains the life of the Mangrove by preserving it in brackish water as well as in pots. Mangroves planted with freshwater can still grow, but their growth is slow, unlike if they live in their habitat [4]

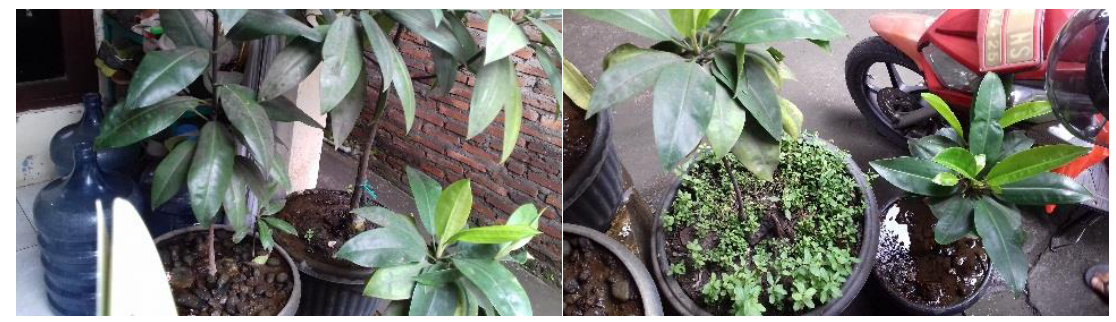

Fig.1 Planting Mangroves in Pots with Freshwater.

Media land is not from its habitat, and Freshwater can also grow well. METAL members can trust the selection of a place with continuous monitoring of the Mangrove sunlight to 
develop in new areas. Utilization of the earth's energy such as soil, water and the air is important in the new adaptation of mangroves.

\section{CONCLUSION}

The METAL organization is formed because of the system of social groups that occur in a family way; one member knows each other well. The organization was formed with MMEP (Maroon Mangrove Edu Park) ecological tourism, not an organization formed because of the recruitment of a tourist area so that the love and sustainability of Mangroves have been embedded in its members. The existence of MMEP as an icon for the introduction of METAL so that the permanent closure of MMEP does not mean that the METAL icon as a useful plant planter in the present and future is cut off and disbanded on the spot. Creating new ideas for coastal communities in Tawang Mas is METAL's form of creativity in embracing the community to develop Mangrove sustainability, although not in seawater.

\section{REFERENCE}

1. Risti Ainur Rahma, Optimalisasi Wisata Edukasi Kawasan Konservasi Hutan Mangrove Pasarbanggi Melalui Buku Panduan, Skripsi, Jurusan Geografi Fakultas Ilmu Sosial, Universitas Negeri Semarang, hal 11, (2019)

2. Doddy S.Singgih, Metode Analisis Fungsi Lahan dalam Perspektif Sosiologi Pedesaan. Masyarakat Kebudayaan dan Politik, Th XII, No 3, Juli, 1-8. hal 4-5 (1999)

3. A. Terry Rambo, Conceptual Approaches to Human Ecology, East-West Environment and Policy Institute Research Report No. 14, Center Honolulu, Hawaii. P 7. (1983)

4. Sarno, Penanaman Mangrove Di Dalam Pot, Bioeksperimen, Program Studi Ilmu Pertanian, Pascasarjana Universitas Sriwijaya, Volume 2 No. 1, Maret, hal 21, ISSN 2460-1365 (2016)

5. Desy Melinda Sari, Suryanti, Bambang Sulardiono, Management Of Mangrove Ecosystem As Ecotourism Area In Maroon Mangrove Edu Park (MMEP) Semarang, Central Java, Departemen Sumberdaya Akuatik Fakultas Perikanan dan Ilmu Kelautan, Universitas Diponegoro, Management Of Aquatic Resources, Journal Of Maquares Volume 8, Nomor 1, Hal. 37 (2019)

6. Sri Suryaningsum, Perspektif Struktur Organisasi (Tinjauan Sebagai Pengubah Perilaku), Jurnal Pendidikan Akuntansi Indonesia Vol. VI No. 1 hal. 63 (2008)

7. Ghizella O. Ramena, Cynthia E. V. Wuisang \& Frits O. P. Siregar, Pengaruh Aktivitas Masyarakat Terhadap Ekosistem Mangrove Di Kecamatan Mananggu, S1 Program Studi Perencanaan Wilayah \& Kota, Universitas Sam Ratulangi Manado, Jurnal Spasial Vol 7. No. 3, ISSN 2442-3262, Page 343 (2020)

8. Risti Ainur Rahma, Optimalisasi Wisata Edukasi Kawasan Konservasi Hutan Mangrove Pasarbanggi Melalui Buku Panduan, Skripsi, Fakultas Ilmu Sosial Universitas Negeri Semarang, Hal 35 (2019) 